\title{
NOTE ON TRANSLITERATION AND DATES
}

Ottoman Cairo was a multi-lingual society, in which both Arabic and Turkish were prominent. In my opinion, it is unnecessary, and even anachronistic, to insist rigidly on using either the Arabic or the Ottoman Turkish system for transliteration. I have used both. In general, the names of people from and places in Egypt or the Arab provinces are transliterated according to the Arabic system, whereas those from Istanbul, Anatolia, and Rumelia are transliterated under the Ottoman system. In the interests of readability, within the text I use the Ottoman system for some Turkish titles that appear within Egyptian/Arabic names. An example is the Egyptian chronicler Aḥmad Çelebi ibn ' Abd al-Ghanī. However, for accuracy's sake, in citations I transliterate consistently according to the language of the text cited (so the above chronicler becomes Aḥmad Shalabī ibn ${ }^{c}$ Abd al-Ghanī). When a name, title, or other word is well-known in an English rendering, I usually use the English form; hence Pasha, Sultan, ulema, Koran, and so on.

Although it may be hard on the non-specialist reader, I have often opted to retain many Arabic and Turkish technical terms rather than translate them into English. Because much of the argument of this book is concerned with the details of offices and institutions, English words could fudge the issue. Technical terms are transliterated according to my judgment as to whether, in Ottoman Cairo, they were understood as coming from the Arabicate or Ottoman tradition. So, for

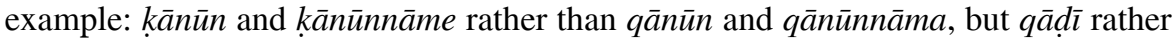
than kadl. In some cases, when a word is part of a proper noun, I transliterate it differently depending on context: the main example of this is that the governor's tribunal in Cairo is called al-Dīwān al- ${ }^{c} \bar{A} l \overline{1}$, but the imperial council in Istanbul is called the Dīvān-i Hümāyūn. Arabic and Turkish terms are explained in the glossary. 
For Arabic, I transliterate according to the system of the International Journal of Middle East Studies, with some alterations. I transliterate jīm as g, following Cairene pronunciation, when it forms part of an Egyptian person or place-name. For example: the name Girgis. I do not assimilate the lām of the definite article to the sun letters (i.e. al-shams rather than ash-shams). I always use full diacritics, including in names and book titles. For Ottoman Turkish, I prefer full transliteration rather than modern Turkish spelling, and I follow the IJMES system.

Although it looks inelegant to readers of Arabic, I pluralize Arabic words in the English way to avoid confusion for non-specialist readers. The only two exceptions are waqf, which I pluralize in the Arabic way as $a w q \bar{a} f$ (this word appears often in the plural, and the Anglicized waqfs is difficult to pronounce) and shuhüd (this is more familiar than the singular in the fixed phrases shuhūd al-ḥal and shuhūd $\left.{ }^{c} u d \bar{u} l\right)$.

In general I use the CE calendar, but when discussing particular cases drawn from the archival records I prioritize the Muslim hijrī calendar ( $\mathrm{AH})$ that the documents use, with equivalent $\mathrm{CE}$ dates in parentheses. Documents issued by the imperial bureaucracy in Istanbul are often dated only to the early (evāyil), mid (evāsit) or late (evähır) part of the month, that is, the 1st-10th, the 11th-20th or the 21st-29th/30th. 